\title{
Response of Sugarcane Enzymes to Variable Light: Variable Illumination Studies of Invertase, ATP- ase and Amylase in Plants Experiencing Nitrate- and Gibberellic Acid-Induced Stress
}

\author{
Alex G. Alexander, Ashok Kumar, Rafael Montalvo-Zapata, \\ and Gene L. Spain 1
}

\section{INTRODUCTION}

In a recent paper (17) ${ }^{2}$ Alexander and Montalvo reported discrete relationships between light and Paraquat in sugarcane. The bipyridilium herbicide was totally dependent upon light for its characteristic desiccative or drying action. The latter was readily delayed by retention of plants in darkness. Quite significantly, however, the dark treatment caused distinct changes in enzyme activity patterns both in the presence and absence of herbicide. By altering the behavior of invertase, amylase, ATP-ase and other enzymes, light assumed an influence over ultimate sucrose yield quite distinct from its commanding position in sucrose synthesis.

The study of light-Paraquat-enzyme relationships underscored significant questions worthy of further exploration: Although light per se cannot be controlled over a field of growing cane, to what extent do controlled agronomic practices alter the action of light? How do factors such as nutrients, water, and chemicals affect the light-enzyme relationships actively determining sugar yield? Initial research designed to clarify these questions is herein reported.

Our approach was to force distinct regimes of growth and sugar-producing capacity upon sugarcane prior to subjecting the plants to variable illumination. Nitrate $\left(\mathrm{NO}_{3}\right)$, the lone nitrogen source, and gibberellic acid (GA) were used to accomplish these effects under greenhouse conditions. Withholding $\mathrm{NO}_{3}$ in sand culture simulates a ripening status, while high $\mathrm{NO}_{3}$ produces the succulent growth and profuse tillering characteristic of pre-ripening stages $(1,2,14)$. GA has aroused broad interest in the sugarcane world as a stimulant of growth and sugar production $(9,10,20,21,22,32)$.

There were four objectives: 1 , To continue evaluation of cane enzymes in darkened and naturally-illuminated sugarcane; 2 , to study prolonged darkness and reillumination effects on enzyme and sucrose constituents of $N$ deficient plants; 3 , to evaluate the same factors in N-rich plants; and 4, to

1 Plant Physiologist, Assistant Biochemist, Assistant Chemist, and Associate Agronomist, respectively, Agricultural Experiment Station, Mayagüez Campus, University of Puerto Rico, Río Piedras, P.R.

2 Italic numbers in parentheses refer to Literature Cited, pp. 475-6. 
explore the capacity of GA to alter light-induced enzyme and sugar changes in sugarcane.

\section{EXPERIMENTAL PROCEDURE}

GROWTH AND PRETREATMENT OF PLANT MATERIALS

A single controlled-light experiment was conducted with immature sugarcane of the variety P.R.980. Plants were grown in HCl-washed quartz sand contained in 2-gallon stoneware pots. Until 11 weeks of age, the plants in each container received 1 liter of nutrient solution and 1 liter of tapwater daily. The standard solution was composed of the following nutrients expressed as meq./liter: Nitrate, 10; phosphate, 6; potassium, 5; calcium; 3; magnesium, 2; and sulfate. Micronutrients, expressed as parts per million, were included as follows: Boron, 0.05; copper, 0.02; manganese, 0.50; zinc; 0.05 ; molybdenum, 0.01 ; and iron, 1.0 .

At 11 weeks, 90 containers were selected for plant uniformity and divided into five groups having 18 containers each. Three of these continued to receive the standard nutrient solution. Of the remaining groups, $\mathrm{NO}_{3}$ was withheld from one, hereafter referred to as the "low $\mathrm{NO}_{3}$ plants", while the other began receiving 50 meq./1. of $\mathrm{NO}_{3}$. The latter group is subsequently termed the "high $\mathrm{NO}_{3}$ plants". At 14 weeks a third set of plants was sprayed with a 0.01 percent GA solution. The 90 -percent potassium salt was employed with Tween 20 serving as wetting agent, and all plants were sprayed until thoroughly wet. This group continued to receive the standard nutrient solution. At 16 weeks the $\mathrm{NO}_{3}$ and GA-treated plants, plus one of the remaining two sets, were moved into a dark chamber described in the previous paper. This was completed at about 9:00 a.m. and initiated the variable illumination treatments. The set of darkened plants previously untreated served as the "chamber" control, while the final group of plants remained in natural light as the "greenhouse" control. After 96 hours the cane was moved out of the dark to the greenhouse where it resumed exposure to natural illumination. The reader should note that greenhouse control plants and reilluminated darkroom plants experienced a normal day-night illumination sequence rather than continuous light.

Darkened plants were situated in four distinct blocks; within each block there were three replicates of the respective treatment. Nutrient applications were discontinued for all plants during the 6 days of variable illumination. Each container received 2 liters of water daily during this phase of the study.

\section{LABORATORY ANALYSES}

Leaves +1 to +4 and immature storage tissues were sampled for sugar and enzyme analyses at $0,2,8,24,48,96,102,120$ and 144 hours. Tissues 
were quick-frozen in a mixture of dry ice and acetone and stored in a freezer. They were lyophilized and ground to pass a 60 -mesh screen prior to extraction. Clarified aqueous extracts of the tissue powder were diluted with 0.25 $\mathrm{N} \mathrm{NaOH}$ and analyzed for sucrose by the resorcinol method of Cardini et al. (21).

Protein was precipitated from clarified water extracts with solid ammonium sulfate at $\mathrm{pH}$ 5.6. All samples were chilled for 30 minutes to increase protein yield. The 0-80 percent fraction was retained for enzyme assay. Precipitated protein was removed by centrifuge, dissolved in a minimum of distilled water, and dialyzed for 2 hours against two changes of distilled water. Appropriate dilutions were prepared from the concentrates and all enzyme assays were completed within 72 hours of tissue extraction. Acid phosphatase and ATP-ase were measured in accordance with procedures described earlier (4), as was invertase (5) and amylase (6). The technique of Sutherland et al. (30) was used to determine water-soluble protein of tissue samples and enzyme dilutions. Enzyme action was computed as specific activity (activity units per mg. of protein).

Composited leaf samples were extracted with water and chromatographed on Whatman no. 1 filter paper, using the solvent mixture butanol-pyridinewater $(6: 4: 3, \mathrm{v} / \mathrm{v})$ in one dimension. Extracts were concentrated by lyophilization prior to spotting on paper. Reference and unknown sugar spots were developed by the silver nitrate method of Dube and Nordin (2S).

\section{RESULTS AND DISCUSSION}

\section{PRETREATMENT EFFECTS OF $\mathrm{NO}_{3}$ AND GA}

Efforts to establish distinct growth and sucrose regimes with $\mathrm{NO}_{3}$ and $\mathrm{GA}$ were successful. Low- $\mathrm{NO}_{3}$ plants were typically stunted and lighter green in color. Newly-emerging leaves were pale green to yellow, and a greater percentage of mature leaves were desiccating and detaching from the young stalks. High- $\mathrm{NO}_{3}$ plants had assumed a deep-green color and were very succulent. They were growing rapidly and had produced an abundance of tillers. Only a few of the older leaves had desiccated and fallen away. Plants treated with GA were experiencing typically high rates of internode elongation. Foliage resembled that of control plants rather than either of the $\mathrm{NO}_{3}$ treatments. There was no unusual number or growth of tillers.

Sucrose values presented in table 1 reflect a "ripening" trend established in low- $\mathrm{NO}_{3}$ plants. Leaf sucrose content was more than double that of either control group. Similar effects of low $\mathrm{NO}_{3}$ were reported earlier $(1,2,9,13)$. It has also been noted that an inverse relationship exists between sucrose content and the activity of acid phosphatase, ATP-ase, and amylase in sugarcane $(1,2,3,7,8)$. This relationship was again observed within the cur- 
rent low- $\mathrm{NO}_{3}$ pretreatment (table 2). The zero-hour data summarized in table 2 shows a marked restriction of each enzyme from the $\mathrm{N}$-deficient plants. High- $\mathrm{NO}_{3}$ generally increased activity for the three catalysts. In the instance of amylase GA treatment suppressed activity well below control values. This effect has also been observed earlier $(11,15)$. Hence, the pretreatments appeared to have given us the physiologically distinct plants we wanted for subsequent studies of light-enzyme relationships.

TABLE 1.-Sucrose content of control sugarcane prior to variable illumination, and of sugarcane experiencing $\mathrm{NO}_{3}$ - and $\mathrm{GA}$-induced stress ${ }^{1}$

\begin{tabular}{|c|c|c|c|c|c|c|}
\hline \multirow{2}{*}{$\begin{array}{l}\text { Sucrose, mg./g., for } \\
\text { tissue }\end{array}$} & \multicolumn{5}{|c|}{ Treatment } & \multirow{2}{*}{ Mean } \\
\hline & $\underset{\text { (greenhouse) }}{\text { Control }}$ & $\begin{array}{c}\text { Control } \\
\text { (chamber) }\end{array}$ & $\begin{array}{l}\text { Low NO} \mathrm{NO}_{2} \\
\text { (o meq./l.) }\end{array}$ & $\begin{array}{l}\text { High NO } \\
\text { (50 meq./1.) }\end{array}$ & $\begin{array}{l}\text { GA }(.01 \\
\text { percent) }\end{array}$ & \\
\hline $\begin{array}{l}\text { Leaf } \\
\text { Immature storage }\end{array}$ & $\begin{array}{l}36 \\
76\end{array}$ & $\begin{array}{l}32 \\
72\end{array}$ & $\begin{array}{r}80 \\
100\end{array}$ & $\begin{array}{l}38 \\
49\end{array}$ & $\begin{array}{l}41 \\
61\end{array}$ & $\begin{array}{l}45 \\
72\end{array}$ \\
\hline Mean & 56 & 52 & 90 & 44 & 51 & \\
\hline
\end{tabular}

${ }^{1}$ Each figure represents the mean of 3 replicates.

TABLE 2.-Leaf enzyme values for control sugarcane prior to variable illumination, and of sugarcane experiencing $\mathrm{NO}_{3}$ - and $\mathrm{GA}$-induced stress ${ }^{1}$

\begin{tabular}{|c|c|c|c|c|c|c|}
\hline \multirow{2}{*}{$\begin{array}{l}\text { Specific activity } \\
\text { at } 0 \text { hours for- }\end{array}$} & \multicolumn{5}{|c|}{ Treatment } & \multirow{2}{*}{ Mean } \\
\hline & $\begin{array}{c}\text { Control } \\
\text { (greenhouse) }\end{array}$ & $\begin{array}{c}\text { Control } \\
\text { (chamber) }\end{array}$ & $\begin{array}{l}\text { Low } \mathrm{NO}_{2} \\
\left(0 \text { meq. } / \mathrm{l}_{.}\right)\end{array}$ & $\begin{array}{l}\mathrm{High} \mathrm{NO} \mathrm{N}_{3} \\
(50 \mathrm{meq} . / \mathrm{l} .)\end{array}$ & $\begin{array}{c}\text { GA (.01 } \\
\text { percent) }\end{array}$ & \\
\hline Phosphatase & 39 & 41 & 27 & 48 & 40 & 39 \\
\hline ATP-ase & 52 & 63 & 36 & 74 & 62 & 57 \\
\hline Amylase & 177 & 150 & 114 & 180 & 106 & 145 \\
\hline Mean & 89 & 85 & 59 & 101 & 69 & \\
\hline
\end{tabular}

1 Each figure represents the mean of 3 replicates.

SUGAR RESPONSE TO VARIABLE ILLUMINATION, $\mathrm{NO}_{3}$ AND GA

Sucrose

As anticipated, darkened plants failed to maintain leaf sucrose values comparable to plants remaining under a normal day-night illumination sequence (table 3, fig. 1). Figure 1, illustrating leaf sucrose for the darkroom and greenhouse controls, shows that the darkening of plants at 9:00 a.m. prevented their recovery of sucrose from the previous night's low. For the ensuing 96 hours the sucrose of darkened plants lagged below, but essen- 
tially parallel with, the sucrose values of greenhouse cane. Most of this "lag" was made up within 6 hours after reexposure to light. At 144 hours there was no difference between the two control groups. The capacity to synthesize sucrose was therefore not impaired by darkness.

It is important to note that the "suppression" of sugars by darkness occurred primarily within the first 2 hours of treatment, and that recovery of this loss took no more than 6 hours. Throughout the study major differences for both sugars and enzymes were encountered during the first few hours of treatment and during the initial hours after reillumination. In other words, the intervals between midmorning and midafternoon, or even between midmorning and late morning, were of extreme importance to the plant. Be-

TABLE 3.-Leaf sucrose conlent of sugarcane given variable illumination, and experiencing $\mathrm{NO}_{3}$ - and $\mathrm{GA}$-induced stress ${ }^{1}$

\begin{tabular}{|c|c|c|c|c|c|c|c|c|c|c|}
\hline \multirow{2}{*}{ Sucrose (mg./g.) for- } & \multicolumn{9}{|c|}{ Harvest periods (hours) for-ncrmal illumination } & \multirow{2}{*}{ Mean } \\
\hline & $\mathbf{0}$ & 2 & 8 & 24 & 48 & 96 & 102 & 120 & 144 & \\
\hline \multirow[t]{2}{*}{ Control, greenhouse } & 36 & 60 & 69 & 59 & 52 & 42 & 68 & 60 & 73 & \multirow[t]{2}{*}{57} \\
\hline & \multicolumn{5}{|c|}{ Continuous darkness } & \multicolumn{4}{|c|}{ Normal illumination } & \\
\hline Control, chamber & 32 & 30 & 30 & 23 & 21 & 15 & 55 & 51 & 72 & 37 \\
\hline $\mathrm{NO}_{3}, 0$ meq./l. & 80 & 63 & 73 & 58 & 41 & 38 & 66 & 59 & 63 & 60 \\
\hline $\mathrm{NO}_{3}, 50$ meq. $/ 1$ & 38 & 33 & 29 & 22 & 26 & 19 & 60 & 41 & 77 & 38 \\
\hline GA, .01 percent & 41 & 38 & 33 & 24 & 24 & 18 & 83 & 58 & 72 & 43 \\
\hline Mean & 45 & 45 & 47 & 37 & 33 & 26 & 66 & 54 & 71 & \\
\hline
\end{tabular}

1 Each figure represents the mean of 3 replicates.

tween the 96- and 102-hour harvests we were measuring the relationships of prolonged darkness to light, as well as of midmorning to midafternoon.

Sucrose values for immature storage tissue also underscore the first critical hours of light treatment (table 4). As illustrated by figure 2, darkened cane failed to match the early sucrose accumulations being performed by greenhouse plants. Again the critical factor was the timing of darkness rather than its duration. After $S$ hours both sets of plants had comparable sucrose values which did not again deviate appreciably until the final harvest.

During the previous study Alexander and Montalvo (17) observed major sucrose increases in both leaf and immature storage tissues within a few hours after reillumination. It was concluded that some immediate sucrose transport was active between the two tissues, and that the sucrose accumu- 
lations had reflected rapid synthesis rather than backlogs due to inadequate movement. The present study supports this contention. Among undarkened plants, immature storage tissues clearly increased sucrose during the two periods when morning and afternoon measurements were taken, i.e.,

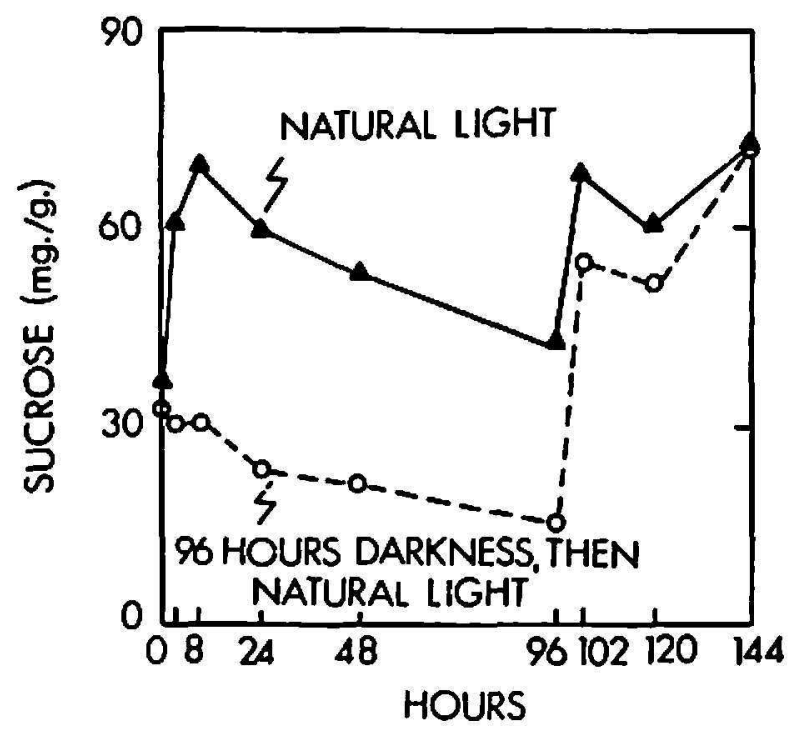

Fig. 1.-Leaf sucrose content of sugarcane exposed to natural illumination, and sucrose decline with subsequent recovery in sugarcane subjected to 96 hours of darkness followed by natural illumination.

T.unE 4.-Sucrose conlent of immature storage tissues from sugarcane given variable illumination, and experiencing $\mathrm{NO}_{3}$ - and $\mathrm{GA}$-induced stress ${ }^{1}$

\begin{tabular}{|c|c|c|c|c|c|c|c|c|c|c|}
\hline \multirow{2}{*}{ Sucrose (mg./g.) for- } & \multicolumn{9}{|c|}{ Harvest periods (hours) for-normal illumination } & \multirow{2}{*}{ Mean } \\
\hline & $\mathbf{0}$ & 2 & 8 & 24 & 48 & 96 & 102 & 120 & 144 & \\
\hline \multirow[t]{2}{*}{ Control, greenhouse } & 72 & 123 & 138 & 70 & 91 & 50 & 109 & 49 & 52 & \multirow[t]{2}{*}{84} \\
\hline & \multicolumn{5}{|c|}{ Continuous darkness } & \multicolumn{4}{|c|}{ Normal illumination } & \\
\hline Control, chamber & 62 & 62 & 43 & 66 & 90 & 57 & 83 & 60 & 44 & 63 \\
\hline $\mathrm{NO}_{3}, 0$ meq. $/ 1$ & 100 & 80 & 84 & 88 & 70 & 53 & 67 & 56 & 46 & 72 \\
\hline $\mathrm{NO}_{3}, 50$ meq. $/ 1$ & 49 & 35 & 43 & 65 & 73 & 54 & 94 & 62 & 47 & 58 \\
\hline GA, .01 percent & 61 & 40 & 67 & 60 & 81 & 47 & 94 & 46 & 51 & 61 \\
\hline Mean & 69 & (68 & 75 & 69 & 81 & 52 & 89 & 55 & 48 & \\
\hline
\end{tabular}

1 Each figure represents the mean of 3 replicates.

between zero and 8 hours, and between 96 and 102 hours. On the other hand, Hartt el al. (2.) have shown that only a fraction of the sucrose moving from leaf blades to storage tissues passes upward to the growing point. Immature storage tissues would not necessarily reflect the rate of sucrose transport to 
stalks, and the latter movement has to be regarded as a potentially limiting factor in sucrose synthesis.

Leaf sucrose data lends support to the earlier suggestion that darknessinduced stress may stimulate sucrose-forming mechanisms (17). For example, between 96 and 102 hours, the greenhouse control plants accomplished a 60-percent increase of leaf sucrose (fig. 1). During the same 6-hour period the previously-darkened but newly-illuminated plants increased sucrose by more than 260 percent. Factors other than synthesis are undoubtedly involved here, yet the rate of sucrose recovery after reillumination is undeniably impressive.

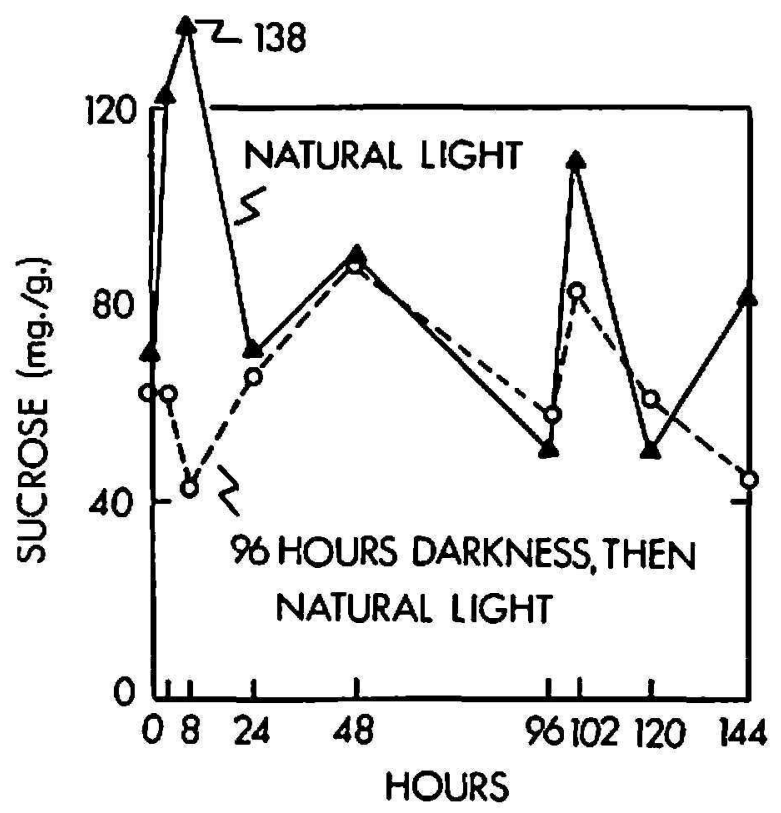

FIG. 2.-Sucrose content of immature storage tissue from sugarcane given variable illumination. Sucrose was greatly increased between 0 and 8 hours (between 9:00 a.m. and 5:00 p.m.) in plants under natural illumination. Similar increases did not occur in darkened sugarcane.

\section{GA Effects on Sucrose-Light Relationships}

Improved synthesis efficiency was also evidenced in GA-treated cane (table 3, fig. 3). We have long suspected that GA stimulates sucrose biosynthesis as a function distinct from its growth effects. In vitro experiments have shown that GA can speed the assembly of sucrose from fructose plus LDPG or glucose-1-phosphate (12). Greenhouse studies revealed increases in leaf sucrose following GA treatment $(9,10,11)$. However, in vivo evidence of the GA effect has been difficult to produce owing to the confounding nature of sucrose transport in cane. A unique opportunity was currently afforded to evaluate sucrose-forming potential in GA-treated and non-trented plants. During the limited period between 96 and 102 hours, the true po- 
tential of control and GA plants could be examined with little interference either from residual or newly-formed sucrose. Since cane leaves have very limited storage capacity the positive GA effects would logically fade away as leaf saturation was approached. Careful examination of figure 3,A shows that darkened, GA-treated plants did recover sucrose far more effectively than did darkened controls. As mentioned earlier, recovery in darkroom control plants was itself quite remarkable when compared to greenhouse controls, but nonetheless it was inferior to that of GA-stimulated cane.

Further evidence that GA was active in sucrose synthesis is illustrated by

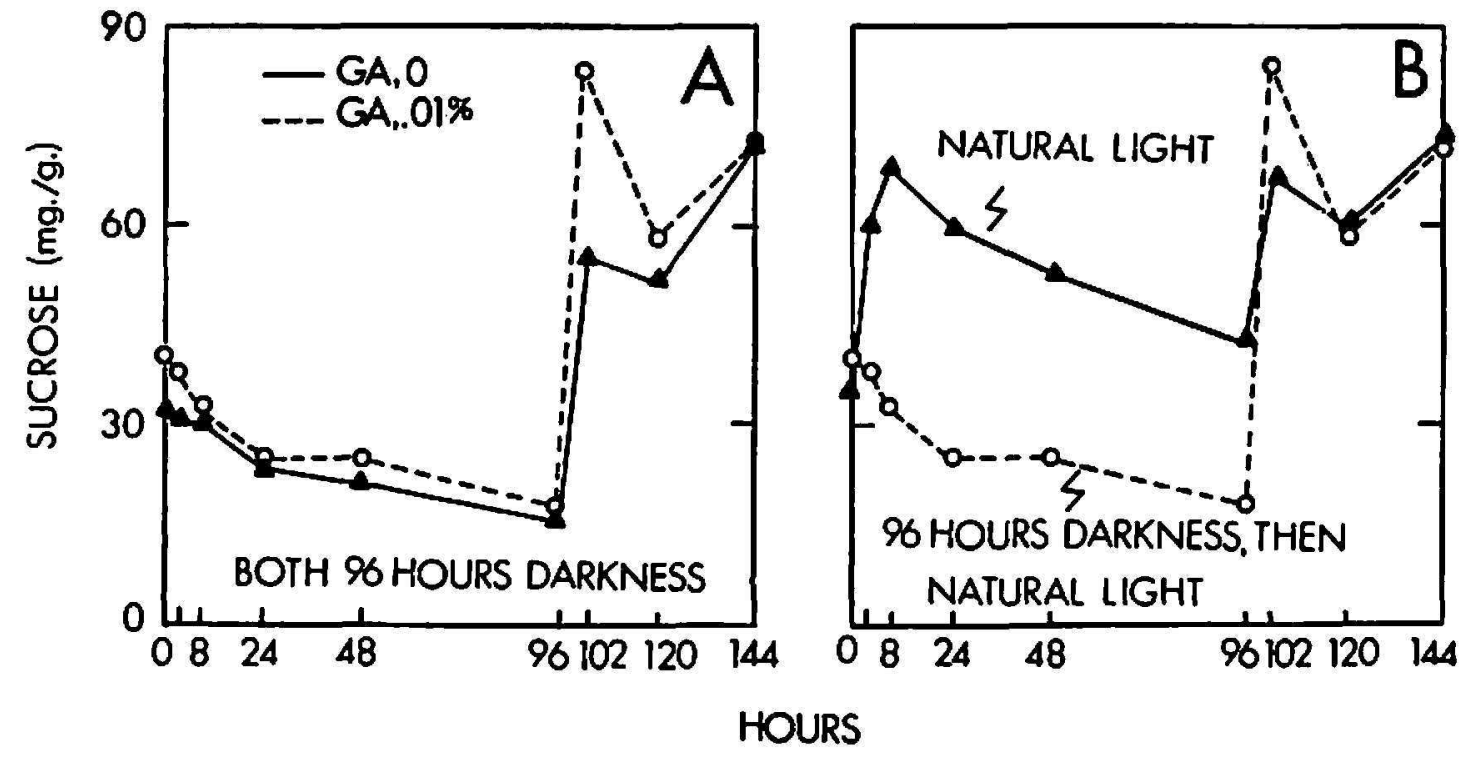

Fig. 3.-Effects of variable light and GA pretreatment on sucrose content of sugarcane leaves: A, Sucrose decline during 36 hours of darkness, followed by superior recovery in GA-treated plants after reillumination. $B$, Sucrose content of darkened, GA-treated plants as compared with non-treated cane given natural illumination. The rate of sucrose increase between 96 and 102 hours was vastly superior for plants sprayed with GA.

figure 3,B. By superimposing GA sugar values over those of greenhouse controls, i.e., over plants never subjected to darkness or GA stress, we see that within 6 hours the GA group made good their sucrose lost in darkness, and then surpassed the morning to afternoon increases being performed by greenhouse cane. As expected, the GA and control plants reverted to comparable sucrose values by 120 hours, indicating that transport rather than synthesizing potential was becoming a limiting factor. A practical implication here is that GA treatment of sugarcane may increase ultimate sucrose potential but still not achieve sucrose increases so long as factors such as light, water, and temperature do not permit adequate transport. On the other hand, GA might promote sporadic increases, perhaps for an hour or 
two during the early morning, or at other periods when leaves are not saturated and transport is non-limiting.

\section{$\mathrm{NO}_{3}$ Effects on Sucrose-Light Relationships}

A very significant finding of this study was the speed and thoroughness with which variable illumination "wiped out" the sucrose differentials established by $\mathrm{NO}_{3}$ and GA pretreatments. Leaf sucrose values for the variable $\mathrm{NO}_{3}$ plants (table 3 ) illustrate this point. In less than 2 hours of darkness the sucrose differences between low- $\mathrm{NO}_{3}$ and greenhouse-control plants were nullified. These differentials did not reappear after illumination. Within the

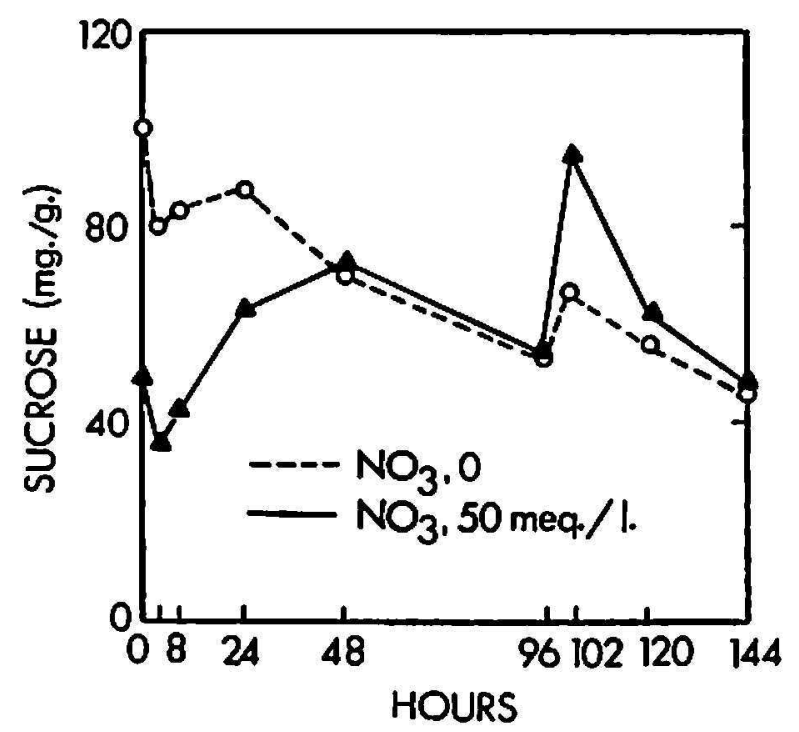

FIG. 4.--Sucrose content of immature storage tissue from two groups of sugarcane given variable illumination. One group was given no $\mathrm{NO}_{3}$ while the other received excessive amounts for five weeks prior to light treatments. All plants were then subjected to 96 hours of darkness followed by reexposure to a normal day-night sequence.

darkroom, low- $\mathrm{NO}_{3}$ cane did retain relatively higher sucrose values than did any other darkened group. But again, when reintroduced to light, low- $\mathrm{NO}_{3}$ plants did not respond more readily than those of other treatments. Reillumination actually removed the remaining sucrose evidence of low- $\mathrm{NO}_{3}$ stress. Plants pretreated with excessive $\mathrm{NO}_{3}$ responded no differently to variable illumination than did control canc. Therefore the loss of a simulated ripening status by the low- $\mathrm{NO}_{3}$ group does not appear to be related to $\mathrm{N}$ deficiency.

Sucrose values for immature storage tissue show no major effect of $\mathrm{NO}_{3}$ pretreatments on subsequent response to light (fig. 4). Illumination was clearly the dominant factor. Regardless of nutritional status, sucrose values began to converge after $\$$ hours of darkness and by 48 hours they were identical. The two groups of plants then experienced a common sugar decline 
between 48 and 96 hours. The high- $\mathrm{NO}_{3}$ cane did respond more readily upon removal to light as evidenced by the high sucrose value at 102 hours (fig. 4). Since sucrose translocation as well as synthesis is reflected here (17), this is possibly accountable to the better physical condition of high- $\mathrm{NO}_{3}$ cane. These plants appeared to be more turgid and probably possessed the favorable water status needed for sugar movement (25). Quite typically, the $N$ -

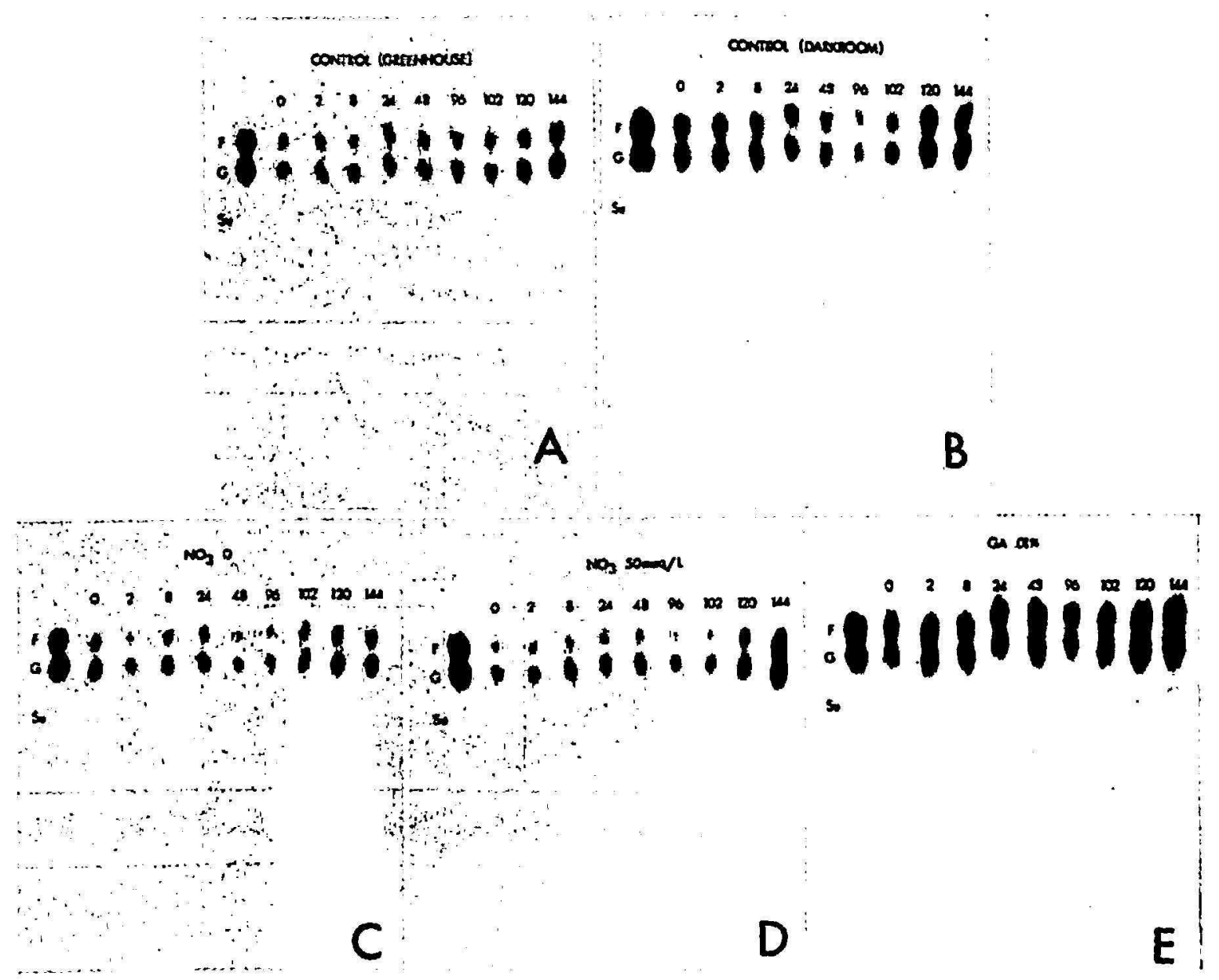

FIG. 5.-Paper chromatograms illustrating fructose, glucose and sucrose in aqueous leaf extracts from two control groups of sugarcane plus sugarcane pretreated with variable $\mathrm{NO}_{3}$ and $\mathrm{GA}$ prior to differential light exposure. Numerals refer to hours of light treatment. The letters "F, $G$ and Su" appearing at the left-hand margin signify reference fructose, glucose and sucrose, respectively.

deficient plants bore a higher percentage of desiccating leaves. Not only are the blades yellower and drier, but sheaths of such leaves are less firmly bound to the stalk. It is probable that $\mathrm{N}$-deficient cane is less able to move sucrose at a non-limiting rate during periods of maximum synthesis.

Paper Chromatography of Leaf Sugars

Chromatography of fructose, glucose and sucrose in foliar preparations generally support conclusions already drawn for leaf sucrose (fig. 5). Figure 
5,A illustrates the general continuity of the three major sugars among control plants retained in the greenhouse under normal illumination. Figure 5,B shows that each sugar gradually declined in darkness, followed by abrupt recovery of sucrose between 96 and 102 hours, and subsequent recovery of reducing sugars. Very likely the newly-produced fructose and glucose passed directly into sucrose until the latter saturated the leaves and became a rate-limiting factor. Quite striking was the GA-induced production of reducing sugars as well as accelerated sucrose recovery (fig. 5,E). This suggests that photosynthesis in general is stimulated by GA in addition to the final stages of sucrose biosynthesis. The improved retention of sucrose in darkened, low- $\mathrm{NO}_{3}$ plants is evident in figure $5, \mathrm{C}$, as is an unexpected in-

TABLE 5.-Invertase activity of sugarcane given variable illumination, and experiencing $\mathrm{NO}_{3}$ - and $\mathrm{GA}$-induced stress ${ }^{1}$

\begin{tabular}{|c|c|c|c|c|c|c|c|c|c|c|}
\hline \multirow{2}{*}{ Specific activity for- } & \multicolumn{9}{|c|}{ Harvest periods (hours) for-normal illumination } & \multirow{2}{*}{ Mean } \\
\hline & $\mathbf{0}$ & 2 & 8 & 24 & 48 & 96 & 102 & 120 & 144 & \\
\hline \multirow[t]{2}{*}{ Control, greenhouse } & 7.4 & 9.6 & 4.2 & 11.1 & 9.0 & 7.1 & 3.4 & 6.0 & 5.9 & \multirow[t]{2}{*}{7.1} \\
\hline & \multicolumn{5}{|c|}{ Continuous darkness } & \multicolumn{4}{|c|}{ Normal illumination } & \\
\hline Control, chamber & 9.3 & 10.7 & 7.0 & 9.2 & 3.3 & 2.6 & 2.7 & 5.8 & 9.4 & 0.7 \\
\hline $\mathrm{NO}_{3}, 0$ meq./l. & 9.9 & 9.7 & 9.4 & 5.8 & 3.4 & 3.1 & 3.5 & 4.4 & 7.7 & 6.3 \\
\hline $\mathrm{NO}_{3}, 50$ meq. $/ 1$. & 10.9 & 11.7 & 7.3 & 6.6 & 3.5 & 2.5 & 2.9 & 4.2 & 9.4 & 6.6 \\
\hline GA, .01 percent & 8.1 & 13.1 & 4.4 & 7.4 & 3.6 & 2.5 & 3.5 & 6.3 & 8.2 & 6.3 \\
\hline Mean & 9.1 & 10.9 & 6.5 & 8.0 & 4.6 & 3.6 & 3.2 & 5.3 & 8.1 & \\
\hline
\end{tabular}

1 Each figure represents the mean of 3 replicates.

crease in reducing sugars for high- $\mathrm{NO}_{3}$ cane following reillumination, figure $5, \mathrm{D}, 144$ hours.

\section{EXZYME RESPONSES TO VARIABLE ILLUMINATION, $\mathrm{NO}_{3}$ AND GA}

\section{Invertase}

Alexander and Montalvo (17) encountered an extreme sensitivity of cane invertase to Paraquat and light. Both Paraquat and darkness produced identical decline patterns. Reexposure to light gave more than complete recovery in Paraquat-free plants, while those sprayed with the herbicide made no response. It was concluded that invertase synthesis required light, and that Paraquat, or a photoreduced free-radical of Paraquat, had irreversibly blocked the light-sensitive reaction.

The present study verified a darkness effect upon invertase (table 5). 
Figure 6 illustrates a severe decline between 24 and 48 hours of darkness, and full recovery some 48 hours after reillumination. Also evident are marked variations between morning and afternoon sampling periods, i.e., zero vs. 8 hours and 96 vs. 102 hours. Quite curiously, this daily fluctuation did not at first seem to rely on direct light exposure. This suggests that invertase was responding to an endogenous plant rhythm only indirectly related to light. Invertase of darkened plants clearly attempted to fluctuate in the manner of illuminated plants during the first day (fig. 6). The invertase fluctuation was modified by darkness at 8 and 24 hours, and after 96 hours the darkened invertase did not respond to sampling-period differentials.

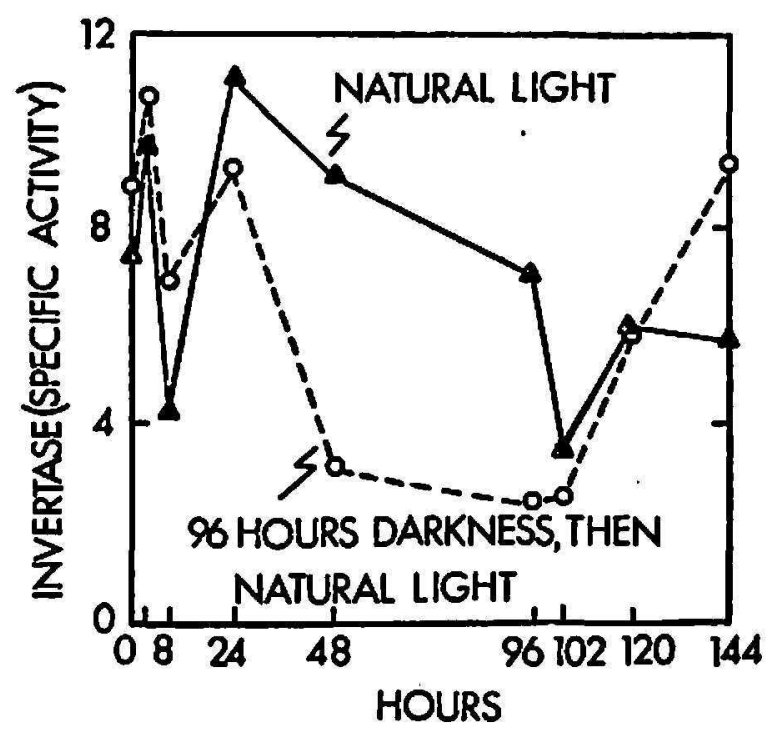

Fra. 6.-Invertase decline in darkened sugarcane followed by recovery after re. illumination.

\section{GA Effects on Light-Invertase Relationships}

While planning this study a major question we hoped to answer was whether GA suppressed invertase, as our own findings had implied $(11,15)$, or whether GA stimulated invertase synthesis, as Kaufman et al. (27) had demonstrated with Avena. Paleg $(28,29)$ reported that GA stimulated amylase synthesis in barley endosperm. By correlating cane growth rate with invertase activity Hatch and Glasziou (26) implied that a growth stimulant such as GA could act by increasing invertase synthesis.

The present experiment did reveal an early GA enhancement of invertase's sensitivity to darkness (table 5, fig. 7), but no evidence was found of a GA effect upon invertase synthesis. In figure 7 the reader can observe a GA stimulation of the enzyme at the 2-hour harvest. Yet between 2 and 8 hours GA effected extremely severe suppression. After 24 hours there was no detectable difference in invertase behavior among GA-treated and non-treated 
cane. GA notably failed to arrest the darkness-induced invertase decline. Still more important, GA did not help to recover invertase upon reillumination, as would logically have been the case had GA improved the invertase synthetic potential. Had our test plant been Avena we would assume that GA does stimulate invertase production and that darkness had destroyed this potential. However, we must conclude that in sugarcane GA might stimulate or suppress existing invertase at a given moment, but it does not affect de novo invertase production.

This study was not designed to tell specifically what happens to a darkened enzyme. However, it is obvious from figure 7 that the invertase present from 48 hours onward had been modified by darkness. The extremely

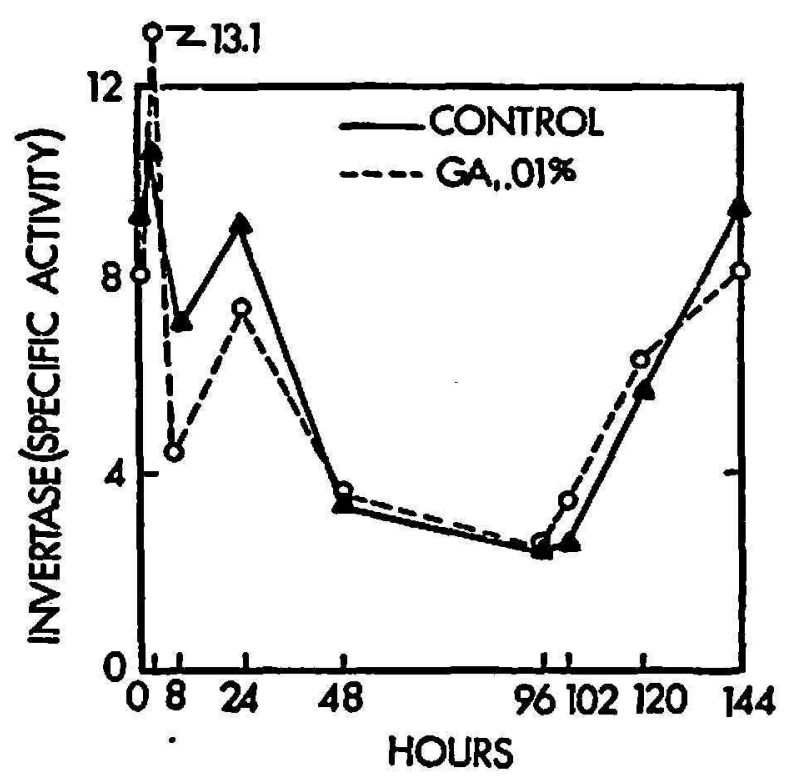

FrG. 7.-Effects of GA pretreatment on the response of sugarcane invertase to variable illumination.

"jumpy" enzyme measured at 2 and 8 hours had thoroughly calmed during the final two-thirds of the study.

\section{$\mathrm{NO}_{3}$ Effects on Light-Invertase Relationships}

Invertase in $\mathrm{N}$-deficient plants was not greatly affected by variable illumination (table 5, fig. 8,A). Although of a lower magnitude, its behavior pattern matched that of control plants during the first 24 hours of darkness. It did not decline thereafter as did control invertase, and only a sluggish increase was noted after reexposure to light. Plants given high $\mathrm{NO}_{8}$ were far more sensitive to light variables (fig. 8,B). Invertase experienced severe decline up to 96 hours and thereafter made a strong recovery in a pattern virtually identical to control plants. As was true of $\mathrm{GA}$, high $\mathrm{NO}_{3}$ failed completely to alleviate the invertase suppression by darkness. 


\section{Amylase-Light Relationships}

Within the area of enzyme-sucrose relationships amylase must be reckoned as one of sugarcane's great mysteries. Experiments have repeatedly shown that this enzyme is a critical factor in determining the level of sucrose to be produced and retained by sugarcane $(1,2,8,18,16)$. For example, amylase suppression was found to be a common denominator in the high sucroseforming capacity of cane under deficiency stress of $\mathrm{NO}_{3}$, calcium, potassium and phosphorus (18). As previously mentioned, the low- $\mathrm{NO}_{3}$ plants in this study had experienced amylase decline prior to receiving their light variables (table 2). Alexander and Montalvo (17) noted that the herbicide Paraquat stimulated amylase under natural light but failed to do so in dark-
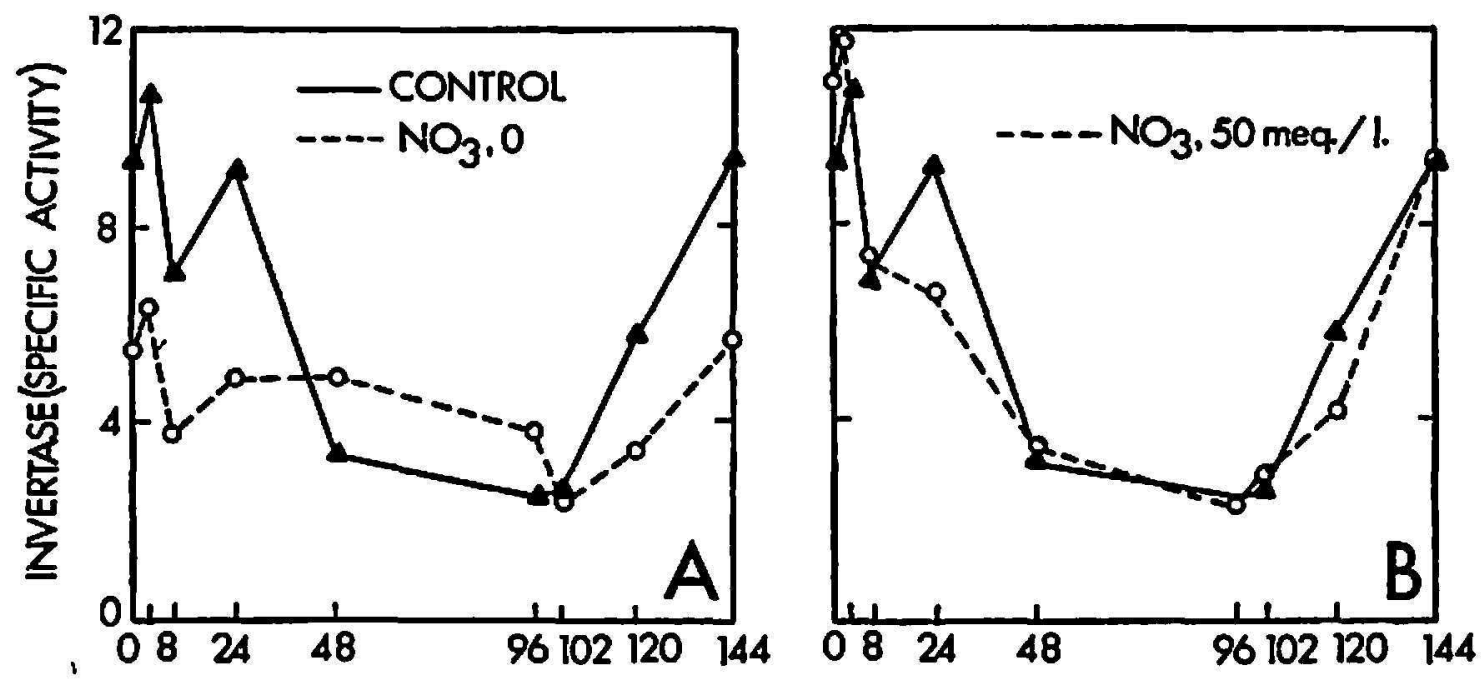

HOURS

Fra. 8. -Effects of variable illumination on invertase of sugarcane pretreated for five weeks with low $\mathrm{NO}_{3}(A)$, and with excessive $\mathrm{NO}_{3}$ (B), in sand culture.

ened plants, or in the same plants when reexposed to light. Presumably, the enzyme was so modified during darkness that the Paraquat radical could not form a correct enzyme-herbicide configuration needed for amylase stimulation. There was no way of proving whether a dark reaction had occurred against the free enzyme, or whether a non-toxic, enzyme-Paraquat complex had been active in the darkened phase. It was in this context that we hoped to learn whether a direct relationship existed between light supply and amylase content, and, if so, whether this relationship could be modified by $\mathrm{NO}_{8}$ or $\mathrm{GA}$.

Leaf amylase was not appreciably affected by darkness. Significant changes were recorded for the enzyme in immature storage tissue. In leaves, amylase was slightly less active among darkroom controls at zero hours (table 6), and this differential was maintained until after the cane was 
reexposed to light. However, in immature storage tissue, the amylase of darkened control plants increased activity over undarkened controls after 8 hours (table 7, fig. 9). This is the type of pattern one would expect for an

TABLE 6.-Leaf amylase activity of sugarcane given variable illumination, and experiencing $\mathrm{NO}_{3}$ - and $\mathrm{GA}$-induced stress ${ }^{1}$

\begin{tabular}{|c|c|c|c|c|c|c|c|c|c|c|}
\hline \multirow{2}{*}{ Specific activity for- } & \multicolumn{9}{|c|}{ Harvest periods (hours) for-normal illumination } & \multirow{2}{*}{ Mean } \\
\hline & 0 & 2 & 8 & 24 & 48 & 96 & 102 & 120 & 144 & \\
\hline \multirow[t]{2}{*}{ Control, greenhouse } & 177 & 134 & 136 & 125 & 130 & 75 & 87 & 73 & 57 & \multirow[t]{2}{*}{110} \\
\hline & \multicolumn{5}{|c|}{ Continuous darkness } & \multicolumn{4}{|c|}{ Normal illumination } & \\
\hline Control, chamber & 150 & 111 & 108 & 109 & 116 & 61 & 63 & 74 & 83 & 97 \\
\hline $\mathrm{NO}_{3}, 0$ meq./l. & 114 & 102 & 122 & 115 & 112 & 54 & 57 & 55 & 61 & 88 \\
\hline $\mathrm{NO}_{2}, 50$ meq. $/ 1$ & 180 & 139 & 152 & 130 & 123 & 62 & 79 & 101 & 65 & 115 \\
\hline GA, .01 percent & 106 & 116 & 120 & 100 & 112 & 70 & 64 & 70 & 60 & 91 \\
\hline Mean & 141 & 120 & 128 & 116 & 119 & 64 & 70 & 75 & 65 & \\
\hline
\end{tabular}

1 Each figure represents the mean of 3 replicates.

TABLF 7.-Amylase activity in immature storage tissues of sugarcane given variable illumination, and experiencing $\mathrm{NO}_{3}$ - and $\mathrm{GA}$-induced stress ${ }^{1}$

\begin{tabular}{|c|c|c|c|c|c|c|c|c|c|c|}
\hline \multirow{2}{*}{ Specific activity for- } & \multicolumn{9}{|c|}{ Harvest periods (hours) for-normal illumination } & \multirow{2}{*}{ Mean } \\
\hline & 0 & 2 & 8 & 24 & 48 & 96 & 102 & 120 & 144 & \\
\hline \multirow[t]{2}{*}{ Control, greenhouse } & 38 & 34 & .25 & 42 & 33 & 27 & 30 & 34 & 34 & 33 \\
\hline & \multicolumn{5}{|c|}{ Continuous darkness } & \multicolumn{4}{|c|}{ Normal illumination } & \\
\hline $\begin{array}{l}\text { Control, chamber } \\
\mathrm{NO}_{8}, 0 \text { meq. } / 1 . \\
\mathrm{NO}_{3}, 50 \text { meq. } / 1 \\
\mathrm{GA}, .01 \text { percent }\end{array}$ & $\begin{array}{l}34 \\
31 \\
45 \\
34\end{array}$ & $\begin{array}{l}43 \\
23 \\
40 \\
29\end{array}$ & $\begin{array}{l}23 \\
19 \\
40 \\
34\end{array}$ & $\begin{array}{l}45 \\
19 \\
40 \\
23\end{array}$ & $\begin{array}{l}40 \\
15 \\
40 \\
23\end{array}$ & $\begin{array}{l}47 \\
24 \\
54 \\
34\end{array}$ & $\begin{array}{l}51 \\
21 \\
68 \\
70\end{array}$ & $\begin{array}{l}49 \\
23 \\
62 \\
41\end{array}$ & $\begin{array}{l}58 \\
34 \\
60 \\
44\end{array}$ & $\begin{array}{l}43 \\
23 \\
50 \\
37\end{array}$ \\
\hline Mean & 36 & 34 & 28 & 32 & 31 & 37 & 48 & 42 & 46 & \\
\hline
\end{tabular}

1 Each figure represents the mean of 3 replicates.

enzyme whose natural inhibitors are produced in daylight and destroyed in darkness.

As was true of invertase, some evidence of an endogenous rhythm was observed during the early hours of variable illumination. Activity decline occurred between the 2- and 8-hour harvests, i.e., between 11:00 a.m. and 
5:00 p.m. Since this pattern also was recorded in darkened plants, it again was concluded that light exposure was not a direct requirement. From this behavior it can be inferred that plants recognized the darkness as nothing more than another night, arrived perhaps a bit early.

\section{$\mathrm{NO}_{3}$ Effects on Amylase-Light Relationships}

Both control and $\mathrm{NO}_{3}$-treated sugarcane suffered major reductions in leaf amylase activity in response to prolonged darkness (table 6, fig. 10). Variable $\mathrm{NO}_{3}$ modified slightly the darkness effect but failed to seriously counter the downward trend or to promote a major recovery after reillumination. Plants given high $\mathrm{NO}_{3}$ made some effort to recover activity between 96 and 120 hours, but even these failed to approach the original zero-hour levels.

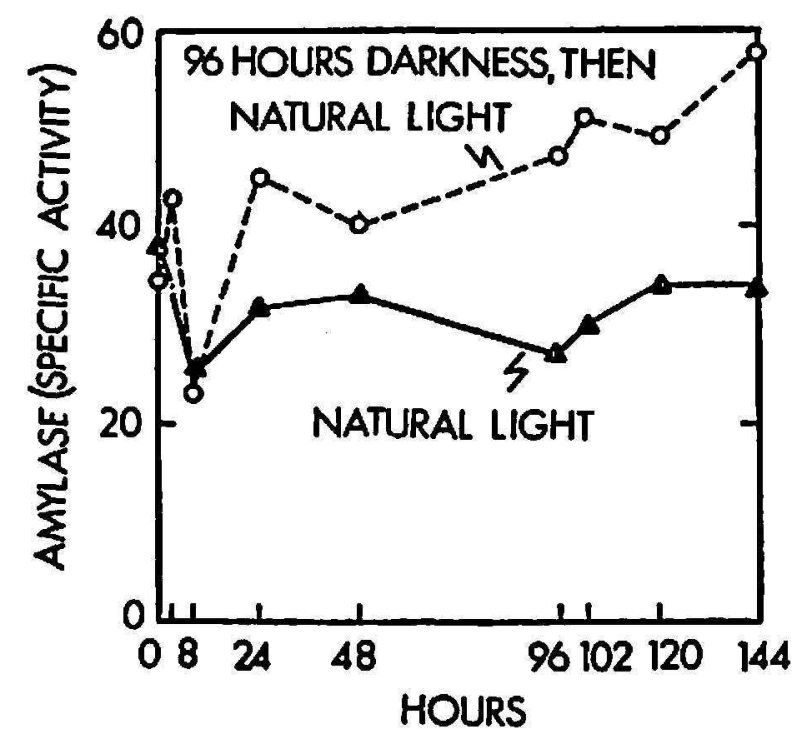

Fro. 9.-Amylase behavior patterns in immature storage tissue of sugarcane given variable illumination.

The low $\mathrm{NO}_{3}$-induced suppression recorded at zero hours was still in effect at the close of the study. On the other hand, high $\mathrm{NO}_{3}$ no longer stimulated amylase at the final harvest as it had done earlier. Even though the plants were once again under natural illumination, the intermediate dark exposure had removed the distinct $\mathrm{NO}_{3}$-amylase relationships achieved during 5 weeks of $\mathrm{NO}_{3}$ pretreatment.

From these results it appears that a foliar mechanism of amylase synthesis requires light, and that an essential component is destroyed during prolonged darkness. The loss of such a constituent would account for the failure of all plants to recover amylase after the dark treatment regardless of nitrogen status.

While amylase in immature storage tissue was not suppressed by darkness, it did underscore the $\mathrm{NO}_{3}$ effects noted for leaf amylase (table 7, fig. 
11). Figure 11,A, shows that the initial low- $\mathrm{NO}_{3}$ suppression remained conspicuously effective regardless of light treatment. Taking into account the critical sucrose roles now assigned to amylase, this could be the most significant finding of the study. Certainly it is one of the few nutritional effects that darkness failed to change. High $\mathrm{NO}_{3}$ generally maintained amylase at or above control values (fig. 11,B). It again promoted amylase increases during the period immediately after reillumination, although in this instance the need is not clear because there was no suppressed or destroyed enzyme system to rejuvenate.

Swain and Dekker (31) observed increased $\alpha$-amylase content and ac-

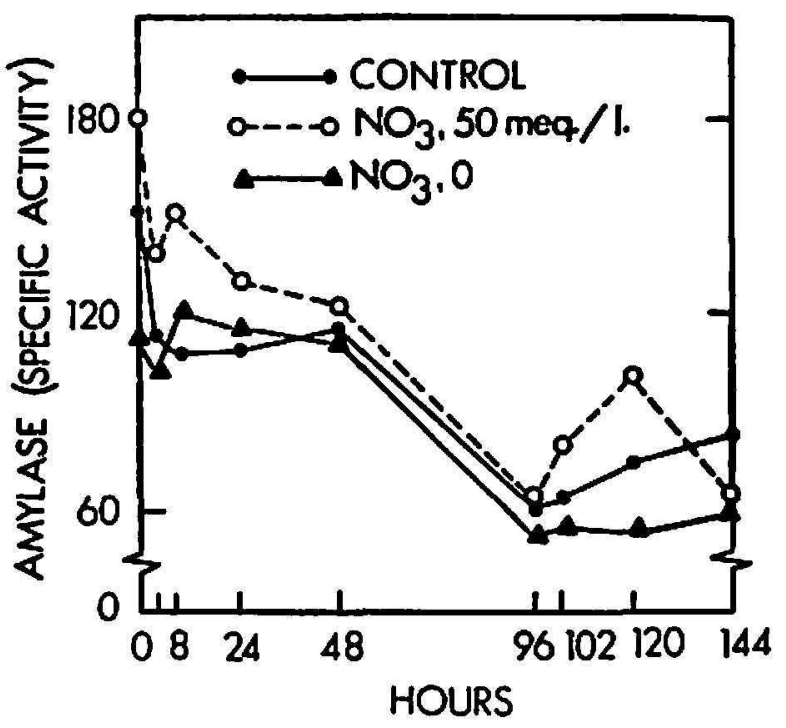

Fig. 10.-Leaf amylase behavior in sugarcane given variable illumination following NO, pretreatments. $\mathrm{NO} \&$ variables modified the amylage behavior pattern; the predominant feature among all plants was enzyme decline caused by 96 hours of darkness.

tivity in darkened pea cotyledons. This was not clearly related to activatorinhibitor changes. They concluded that the $\alpha$-amylase was newly synthesized in darkness, and they further demonstrated the presence of a protein-synthesizing system which required polyuridylic acid for L-phenylalanine incorporation. Although cane amylase is predominately beta (6), a similar synthetic mechanism in cane would respond to variable light as did cane leaf amylase, and to $\mathrm{N}$ extremes as did immature storage tissue amylase.

\section{GA Effects on Amylase-Light Relationships}

Although leaf amylase was not appreciably affected by GA, several amylase changes were recorded in immature storage tissue. In leaves, the initial GA suppression disappeared within 2 hours of darkness (table 6). But in 
storage tissue a suppression not evident at zero hours did develop between 8 and 24 hours of darkness (fig. 12). A tremendous spurt of activity occurred after reillumination at 96 hours. GA thus appeared to increase the enzyme's sensitivity to light.

It is significant that GA interfered with the daily fluctuation pattern described herein as "endogenous rhythm". During the first 24 hours of darkness, GA-treated amylase presented a pattern just opposite of controls (fig. 12), albeit the GA changes were not great. Later, at 96 hours, when control plants scarcely responded to light at all, GA plants produced a veritable blast of amylase activity.
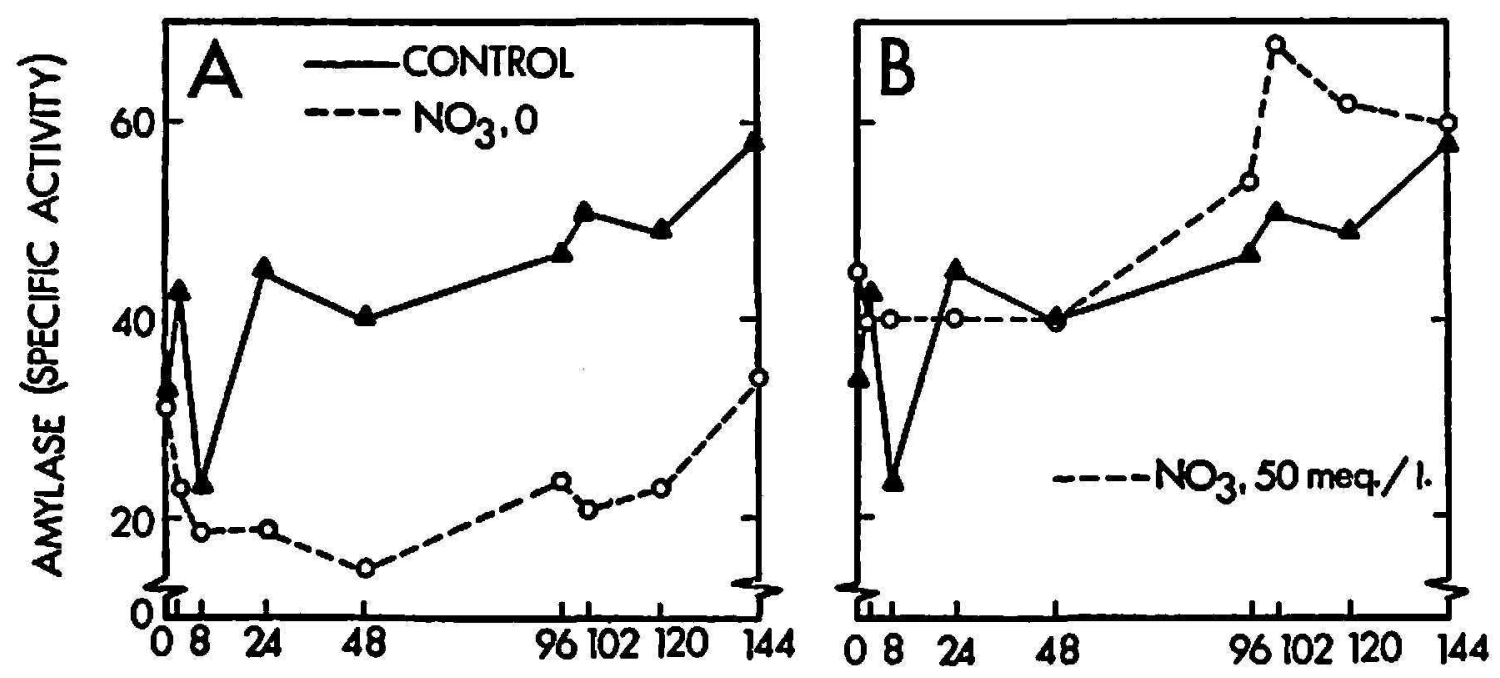

HOURS

Frg. 11.-Amylase behavior patterns in immature storage tissue of sugarcane given variable illumination following $\mathrm{NO}_{3}$ pretreatment: $\mathrm{A}$, Persistence of low $\mathrm{NO}_{2}$ induced suppression regardless of 96 hours of darkness or reillumination. B, Retention of high amylase activity in $\mathrm{NO}_{2}$-rich sugarcane.

Both the magnitude and short duration of the GA-light response present a puzzle. De novo synthesis must have taken place to account for the excessive amylase potential. This does agree with GA stimulatory effects reported in barley endosperm $(28,29)$, but in sugarcane it contrasts with earlier observations of suppression $(11,15)$, not to mention the current suppression only 2 hours before reillumination (fig. 12). Nor is the short duration of high activity easily explained. When sucrose levels made similarly abrupt increases we could attribute them to delayed transport combined with stepped-up synthesis. Sucrose is, after all, an inert product; one readily acted upon as a substrate, or moved about, but itself inactive. This is not the case for amylase or any other essential enzyme. A possible explanation is that inhibitors are also produced in light and that these soon became active against the newly-formed amylase. 


\section{ATP-ase-Light Relationships}

Within 2 hours after beginning the dark treatment foliar ATP-ase experienced a very moderate decline, but one that persisted until the close of the experiment (table 8). Unlike invertase which declined to severely low levels in the absence of light, ATP-ase appears to have accepted a degree of stress which posed no danger to the plant, and which necessitated no compensatory response by its synthetic mechanisms. For example, during the 96- to 102-hour period (9:00 a.m. to 3:00 p.m. of the fourth day), plants outside the darkroom experienced a relatively sharp but temporary activity decline. Darkened plants simply followed suit rather than attempt to regain their losses under the new light supply.

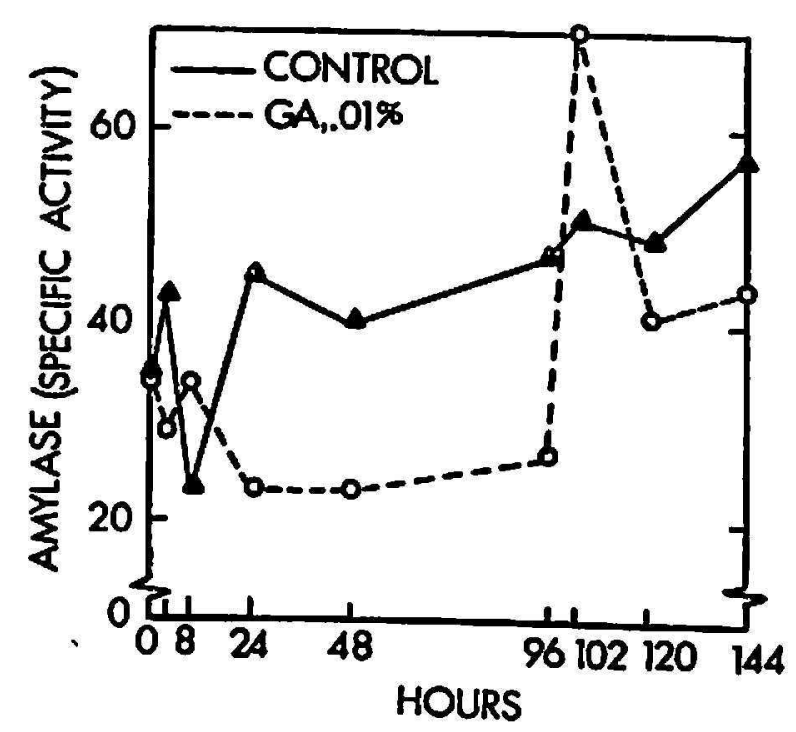

Fie. 12.-Amylase behavior in immature storage tissues from sugarcane pretreated with GA, and then subjected to 96 hours of darkness followed by reillumination.

\section{$\mathrm{NO}_{3}$ Effects Upon ATP-ase-Light Relationships}

ATP-ase data from the variable $\mathrm{NO}_{3}$ groups support the contention that it is a rugged catalyst which will resist suppression beyond some criticallylow level. Figure 13,A illustrates the eventual fate of the low- $\mathrm{NO}_{3}$ suppression active at zero hours. In spite of darkness, which caused ATP-ase losses in control plants, low $\mathrm{NO}_{3}$ caused no appreciable decline beyond that achieved before entry into the darkroom. On the other hand, high $\mathrm{NO}_{8}$ plants experienced a more severe decline than did controls. As illustrated by figure 13,B, high- $\mathrm{NO}_{3}$ values converged on those of low $\mathrm{NO}_{3}$ within 48 hours and remained at comparable levels for 2 days, until light was again provided. The former high $\mathrm{NO}_{3}$ vs. low $\mathrm{NO}_{3}$ differential then was reestablished under natural illumination although not of the severity recorded at the start of light treatments. We conclude from this behavior that a portion 
of the total ATP-ase potential is very sensitive to light and probably requires light in some phase of its production. This protein must also be sensitive to $\mathrm{N}$ status, but the remainder lies beyond the immediate influence of light or $\mathrm{NO}_{3}$ variables of the severity employed here. The resistant ATP-ase level probably is sufficient to perform the enzyme's required functions. It could also represent a second, light.insensitive mechanism of ATP-ase synthesis.

Bennun and Avron (18) describe three ATP-ases in chloroplasts; one proceeding in darkness, a second triggered by light but functioning thereafter in darkness, and a third dependent upon light for continued activity. The first and third are very possibly present in sugarcane. In roughly 50-50

TABLE 8.-Leaf ATP-ase activity of sugarcane given variable illumination, and experiencing $N \mathrm{O}_{\mathrm{g}}$ - and $\mathrm{GA}$-induced stress 1

\begin{tabular}{|c|c|c|c|c|c|c|c|c|c|c|}
\hline \multirow{2}{*}{ Specific activity for- } & \multicolumn{9}{|c|}{ Harvest periods (hours) for-normal illumination } & \multirow{2}{*}{ Mean } \\
\hline & 0 & 2 & 8 & 24 & 48 & 96 & 102 & 120 & 144 & \\
\hline \multirow[t]{2}{*}{ Control, greenhouse } & 52 & 61 & 62 & 58 & 56 & 57 & 44 & 56 & 57 & \multirow[t]{2}{*}{55} \\
\hline & \multicolumn{5}{|c|}{ Continuous darkness } & \multicolumn{4}{|c|}{ Normal illumination } & \\
\hline $\begin{array}{l}\text { Control, chamber } \\
\mathrm{NO}_{3}, 0 \text { meq./1. } \\
\mathrm{NO}_{8}, 50 \text { meq. } / 1 . \\
\mathrm{GA}, .01 \text { percent }\end{array}$ & $\begin{array}{l}63 \\
36 \\
74 \\
62\end{array}$ & $\begin{array}{l}54 \\
35 \\
65 \\
63\end{array}$ & $\begin{array}{l}55 \\
32 \\
53 \\
59\end{array}$ & $\begin{array}{l}46 \\
36 \\
53 \\
51\end{array}$ & $\begin{array}{l}48 \\
34 \\
37 \\
49\end{array}$ & $\begin{array}{l}41 \\
34 \\
36 \\
48\end{array}$ & $\begin{array}{l}34 \\
43 \\
48 \\
54\end{array}$ & $\begin{array}{l}43 \\
34 \\
54 \\
48\end{array}$ & $\begin{array}{l}50 \\
53 \\
40 \\
42\end{array}$ & $\begin{array}{l}48 \\
35 \\
51 \\
53\end{array}$ \\
\hline Mean & 58 & 56 & 52 & 49 & 45 & 47 & 44 & 47 & 40 & \\
\hline
\end{tabular}

1 Each figure represents the mean of 3 replicates.

proportions they would account for the ATP-ase behavior herein reported ${ }^{\circ}$ Quite significantly the same authors reported evidence that light-requiring ATP-ases share part of the energy transport system employed for ATP synthesis during photophosphorylation (19). This is an interesting point of departure for further ATP-ase studies in sugarcane. In the previous study by Alexander and Montalvo (17), reducing-sugar production was recovered after severe restriction by darkness in Paraquat-treated cane leaves. Since this occurred in reilluminated tissues experiencing rapid chlorophyll deterioration, it is believed that a degree of substrate-level phosphorylation was progressing in the absence of a viable light reaction.

It was interesting to note the $\mathrm{NO}_{3}$ effect upon ATP-ase at 96 hours, the time of reillumination. Although in both control groups the enzyme registered a downward shift, both $\mathrm{NO}_{8}$ treatments shifted it upward (fig. 13,B). The important point here is not light per se, or even absolute $\mathrm{NO}_{3}$ level. 
Rather, it is another bit of evidence that once a plant has experienced nutritional stress, be it near-toxic or near-deficient, it becomes in essence a different plant, at least insofar as predictable enzyme behavior is concerned.

\section{GA Effects on Light ATP-ase Relationships}

ATP-ase was altered by GA primarily in immature storage tissue (table 9 ), and this effect was very similar to that described for low $\mathrm{NO}_{3}$ in leaves. For both GA-treated and N-deficient plants ATP-ase declined to about 50 percent of the zero-hour values for darkened control plants. About 48 hours of darkness were required for GA to fully achieve this suppression. $\mathrm{NO}_{3}$-de-
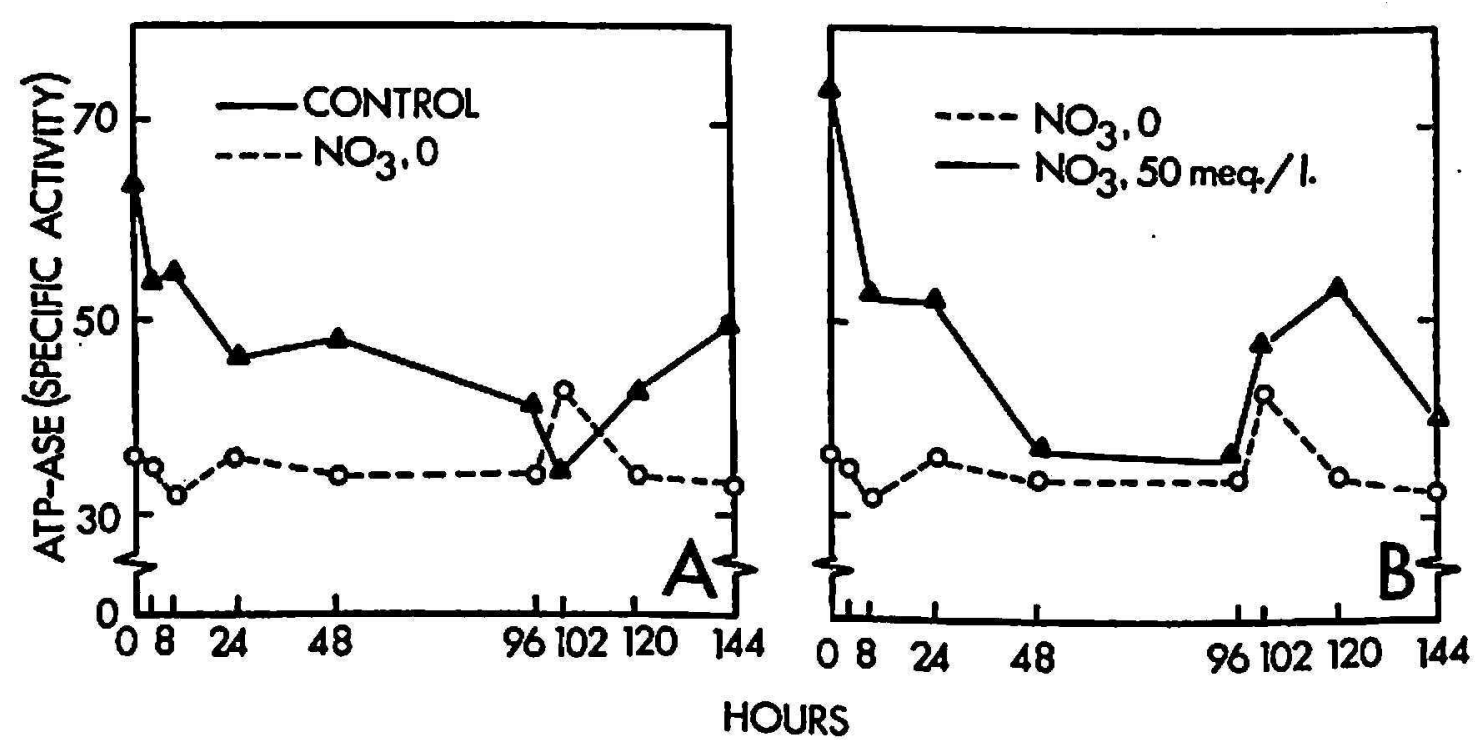

Fra. 13.-Behavior patterns for ATP-ase in leaves of sugarcane darkened for 96 hours and then reexposed to a normal day-night sequence: A, Enzyme suppression among $\mathrm{N}$-deficient plants. $\mathrm{B}$, Convergence of high- and low-NO, values during prolonged darkness.

ficiency had accomplished it prior to dark treatment. As was true of both $\mathrm{NO}_{3}$ groups, GA-treated sugarcane increased ATP-ase between 96 and 144 hours, while greenhouse controls responded with a downward activity shift.

\section{SUMMARY AND CONCLUSIONS}

Prior research has shown that light strongly affects sucrose-enzyme relationships in sugarcane through reactions with the herbicide Paraquat. The present study concerned: 1 , Direct light relationships with invertase, amylase, and ATP-ase; and 2, the behavior of light-enzyme relationships in sugarcane having distinct regimes of growth and sugar production. Plants were pretreated with deficient and excessive amounts of nitrate $\left(\mathrm{NO}_{3}\right)$ and with foliar gibberellic acid (GA) to produce these regimes.

A variable-illumination study was conducted with 16 week old sugarcane 
of the variety P.R.980. All plants were grown by sand culture in the greenhouse under strict water and nutritional control. Five groups of plants were prepared for study: Two of these were given 0 and 50 meq. $/ 1$. of nitrate, respectively, beginning at 11 weeks of age; a third group was sprayed with a 0.01 percent GA solution at 14 weeks; a fourth set accompanied the $\mathrm{NO}_{3}$ and GA as a darkroom control; a fifth group remained in the greenhouse throughout the study as a second control. Randomized block designs were employed with three replicates of each treatment.

At 16 weeks groups one to four were placed in a darkroom. They remained without light for 96 hours, and then were reilluminated by transfer back to their original greenhouse positions. Leaf and immature storage tissues were

TABLE 9.-ATP-ase activity in immature storage tissue of sugarcane given variable illumination, and experiencing $\mathrm{NO}_{\mathrm{z}}$ - and $\mathrm{GA}$-induced stress ${ }^{1}$

\begin{tabular}{|c|c|c|c|c|c|c|c|c|c|c|}
\hline \multirow{2}{*}{ Specific activity for- } & \multicolumn{9}{|c|}{ Harvest periods (hours) for-normal illumination } & \multirow{2}{*}{ Mean } \\
\hline & 0 & 2 & 8 & 24 & 48 & 96 & 102 & 120 & 144 & \\
\hline \multirow[t]{2}{*}{ Control, greenhouse } & 36 & 43 & 28 & 31 & 28 & 32 & 25 & 25 & 23 & 31 \\
\hline & \multicolumn{5}{|c|}{ Continuous darkness } & \multicolumn{4}{|c|}{ Normal illumination } & \\
\hline $\begin{array}{l}\text { Control, chamber } \\
\mathrm{NO}_{3}, 0 \text { meq./1. } \\
\mathrm{NO}_{3}, 50 \text { meq./l. } \\
\mathrm{GA}, .01 \text { percent }\end{array}$ & $\begin{array}{l}41 \\
34 \\
46 \\
34\end{array}$ & $\begin{array}{l}50 \\
26 \\
37 \\
30\end{array}$ & $\begin{array}{l}36 \\
21 \\
42 \\
26\end{array}$ & $\begin{array}{l}40 \\
19 \\
38 \\
25\end{array}$ & $\begin{array}{l}25 \\
15 \\
29 \\
20\end{array}$ & $\begin{array}{l}36 \\
27 \\
34 \\
22\end{array}$ & $\begin{array}{l}28 \\
22 \\
29 \\
26\end{array}$ & $\begin{array}{l}33 \\
21 \\
30 \\
26\end{array}$ & $\begin{array}{l}43 \\
41 \\
42 \\
29\end{array}$ & $\begin{array}{l}37 \\
25 \\
36 \\
26\end{array}$ \\
\hline Mean & 38 & 37 & 31 & 31 & 23 & 30 & 26 & 27 & 36 & \\
\hline
\end{tabular}

1 Each figure represents the mean of 3 replicates.

frozen for sucrose and enzyme assay at $0,2,8,24,48,96,102,120$, and 144 hours. Fructose and glucose changes were studied by paper chromatography.

The following results were obtained:

1. Five weeks of low and high $\mathrm{NO}_{3}$ pretreatments succeeded in establishing simulated ripening and pre-ripening regimes, respectively. These included abnormally high sucrose and low enzyme values for $\mathrm{N}$-deficient cane. Typical growth and sugar effects were achieved with high $\mathrm{NO}_{3}$ and GA.

2. Darkened sugarcane failed to maintain sucrose levels comparable to plants exposed to the usual day-night illumination sequence. Most of the darkroom losses were made up within 6 hours after reexposure to light, indicating no damage to sucrose-forming mechanisms by prolonged darkness. Major sucrose changes were also recorded between morning and afternoon harvests. 
3. Evidence of increased sucrose-forming capacity was recorded among all dark-treated plants. GA:treated sugarcane significantly surpassed other plants in improved synthetic potential. The GA effect was temporary, indicating that translocation of sucrose from leaves soon became a limiting factor. Evidence obtained by paper chromatography of leaf extracts suggests that GA also stimulated photosynthetic production of fructose and glucose. It was concluded that GA can significantly improve the potential of cane to form sucrose, but that this potential might not be realized where sugar transport is a limiting factor.

4. Sucrose differentials in $\mathrm{NO}_{3}$-treated plants were nullified within two hours of darkness. They were not reestablished after transfer of the cane back into light. Both the $\mathrm{NO}_{3}$-rich and $\mathrm{NO}_{3}$-deficient treatments failed to counter the sucrose losses experienced in darkness. GA pretreatment also failed to counter sucrose losses in darkness.

5. $\mathrm{N}$-deficient plants were apparently unable to translocate sucrose readily from leaves to immature storage tissue. This was attributed to poor physical condition rather than to factors of $\mathrm{N}$-metabolism.

6. Invertase declined severely in darkness. Activity was fully recovered after reillumination. This supports earlier evidence of light involvement in invertase synthesis. Invertase varied markedly between morning and afternoon. These daily changes also appeared in darkened plants, suggesting that they stem from "endogenous rhythms" rather than direct light exposure. Prolonged darkness eventually eliminated the daily changes.

7. GA increased the sensitivity of invertase to light, but no evidence of a GA effect upon invertase synthesis was recorded. During early hours of darkness GA both stimulated and suppressed invertase. GA failed to arrest invertase decline in darkness, or to promote invertase recovery after reillumination.

8. Invertase in low- $\mathrm{NO}_{3}$ plants was only slightly affected by variable illumination. Invertase was far more sensitive to light variables in plants given high $\mathrm{NO}_{3}$, but the darkness-induced decline was not alleviated by high $\mathrm{NO}_{3}$.

9. Leaf amylase was suppressed in the absence of light. A foliar synthetic mechanism is proposed in which an essential component is destroyed in darkness. In immature storage tissue the enzyme gradually increased activity in response to prolonged darkness. It was suggested that a natural inhibitor of the enzyme is produced in light and is destroyed in darkness.

10. Variable $\mathrm{NO}_{3}$ modified the dark-induced decline of amylase, but failed to effectively counter the downward trend or to promote major recovery after reillumination. High- $\mathrm{NO}_{3}$ plants achieved partial amylase recovery. A low- $\mathrm{NO}_{3}$ suppression recorded at the beginning of light treatment was still in effect at the close of the study. 
11. A low- $\mathrm{NO}_{3}$ suppression of amylase also persisted in immature storage tissue. This behavior of amylase, frequently recorded in the past, appears to be a common denominator of sugarcane under physiological stress. Failure of light variables to alter the preestablished amylase behavior pattern is regarded as a major finding of the study.

12. Leaf amylase suppression by GA disappeared within 2 hours after dark treatment had begun. However, in immature storage tissue, a GA suppression not evident at zero hours gradually developed among darkened plants. This suppression was followed by a massive increase in amylase immediately after reillumination. It was concluded that GA increased the sensitivity of existing amylase to light, interfered with endogenous amylase rhythm, and promoted amylase synthesis. Evidence of increased synthesis of natural amylase inhibitors was also observed.

13. Foliar ATP-ase experienced moderate but persistent suppression in darkened sugarcane. Activity did not decline lower than 50 percent of zerohour values, and no recovery was made after reexposure to light. ATP-ase of darkened plants followed the same endogenous rhythm as that of greenhouse control plants.

14. The initial zero-hour suppression of ATP-ase was retained but not enhanced in darkness. High- $\mathrm{NO}_{3}$ cane experienced more severe ATP-ase decline than did control or low- $\mathrm{NO}_{3}$ plants. However, this decline did not pass beyond the critical level established by low $\mathrm{NO}_{3}$. It was concluded that about half of the apparent ATP-ase work potential is sensitive to light and $\mathrm{NO}_{3}$ variables. It appears that sufficient of the ATP-ase potential is light insensitive to insure accommodation of essential ATP-ase functions. Two mechanisms of ATP-ase synthesis may be present in sugarcane. Two types of ATP-ase having different sensitivities to light is also suggested.

15. ATP-ase in the two groups of $\mathrm{NO}_{3}$-treated sugarcane responded oppositely to both control-group changes noted immediately after reillumination. Nitrogen stress, regardless of specific $\mathrm{NO}_{3}$ levels, transcended light and endogenous rhythm effects upon ATP-ase.

16. GA caused ATP-ase decline in immature storage tissue. About 48 hours of darkness were required to fully express the GA effect. Again, ATPase resisted decline below the 50-percent level.

\section{RESUMEN Y CONCLUSIONES}

Investigaciones anteriores han demostrado que la luz afecta marcadamente las relaciones entre la sacarosa y las enzimas en la caña de azúcar al reaccionar ésta con el herbicida Paraquat. Este estudio incluyó lo siguiente: 1, Las relaciones directas entre la luz y la invertasa, amilasa y ATP-asa; y 2, el comportamiento de las relaciones entre la luz y las enzimas en la caña de azúcar que ha sido sometida a distintos regímenes de crecimiento y produc- 
ción de azúcar. Las plantas se trataron previamente con cantidades bajas y cantidades excesivas de nitrato $\left(\mathrm{NO}_{3}\right)$ y con ácido giberélico $(\mathrm{AG})$ aplicados foliarmente para establecer estos regimenes.

Se llevó a cabo un estudio de iluminación variable con la variedad P.R.980, de 16 semanas de edad. Todas las plantas se cultivaron en arena en un invernadero con una estricta regulación del agua y los nutrimentos. Se estudiaron cinco grupos de plantas: A dos de los grupos se les suministró 0 y 50 meq./1. de nitrato, respectivamente, empezando a las 11 semanas de edad; un tercer grupo se asperjó con una solución de AG al 0.01 por ciento a las 14 semanas; el cuarto grupo sin tratar se mantuvo como control en la oscuridad; y el quinto permaneció en el invernadero durante el transcurso del estudio como un segundo control. Se usó un diseño de bloques al azar con tres repeticiones para cada tratamiento.

A las 16 semanas los grupos del primero al cuarto se colocaron en una cámara oscura, donde permanecieron por 96 horas, y luego se reiluminaron al transferirlos de nuevo a sus puestos originales en el invernadero. Muestras de tejido foliar y reservante tierno se congelaron para determinar su contenido de sacarosa y enzimas a las $0,2,8,24,48,96,102,120$ y 144 horas. Los cambios que se registraron en el contenido de fructosa y glucosa se estudiaron mediante la cromatografía sobre papel.

Se obtuvieron los siguientes resultados:

1. Cinco semanas de pretratamiento bajo y alto de $\mathrm{NO}_{3}$ lograron establecer regímenes simulados de madurez y premadurez, respectivamente. Estos incluian valores anormalmente elevados de sacarosa y bajos en enzimas para la caña de azúcar deficiente en nitrógeno. Los efectos típicos en cuanto al crecimiento y la formación de azúcar se lograron con los tratamientos altos en $\mathrm{NO}_{3}$ y AG.

2. Las plantas que permanecieron en la oscuridad no alcanzaron niveles de sacarosa comparables a las expuestas a la iluminación usual correspondiente a la secuencia día-noche. La mayor parte de las pérdidas ocurridas en la cámara oscura se recobraron después de volver a exponer las plantas a la luz por 6 horas, indicando así que los mecanismos para la formación de la sacarosa no se afectaron con la oscuridad prolongada. También se registraron cambios mayores en el contenido de sacarosa entre las recolecciones efectuadas por la mañana y por la tarde.

3. Todas las plantas que se colocaron en la cámara oscura demostraron un aumento en la capacidad para la formación de sacarosa. Las tratadas con el AG sobrepasaron a las demás significativamente en cuanto a su potencial para la sintesis. El efecto del AG fue temporero, lo que indica que la translocación de la sacarosa de las hojas pronto se convirtió en un factor limitativo. Los datos obtenidos de los extractos foliares mediante la cromatografía sobre papel sugieren que el AG estimuló también la producción fotosintética 
de fructosa y glucosa. Se concluyó que el AG puede mejorar significativamente el potencial de la caña de azúcar para formar sacarosa, pero que esto sería irrealizable si la translocación del azúcar es un factor limitativo.

4. Las diferencias en sacarosa en las plantas tratadas con $\mathrm{NO}_{3}$ desaparecieron al cabo de 2 horas de permanencia en la oscuridad y no se restablecieron hasta colocar las plantas de nuevo a la luz. Tanto los tratamientos altos en $\mathrm{NO}_{3}$ como los deficientes no lograron compensar las pérdidas en el contenido de sacarosa que tuvieron lugar en la oscuridad. El AG tampoco pudo compensarlas.

5. Las plantas deficientes en nitrógeno aparentemente no podían transportar rápidamente la sacarosa de las hojas al tejido reservante tierno, lo que se atribuyó a pobres condiciones físicas y no a factores del metabolismo del nitrógeno.

6. La invertasa disminuyó severamente en la oscuridad, pero recobró totalmente su actividad después de la reiluminación. Esto sostiene la evidencia previa de la participación de la luz en la síntesis de la invertasa. Los valores de la invertasa variaron marcadamente entre la mañana y la tarde. Estos cambios diarios también ocurrieron en plantas que permanecieron en la oscuridad, lo que sugiere que emanan de "ritmos endógenos" y no de la exposición directa a la luz, ya que la permanencia prolongada en la oscuridad eventualmente eliminó los cambios diarios.

7. El AG aumentó la sensitividad de la invertasa a la luz, pero no se notaron efectos del ácido en la sintesis de la enzima. Durante las primeras horas de oscuridad el AG no solo estimuló sino que también inactivó la invertasa. El AG no pudo detener la disminución de la invertasa a consecuencia de la oscuridad o provocar su recuperación después de la reiluminación.

8. En las plantas tratadas con concentraciones bajas de $\mathrm{NO}_{3}$ la iluminación variable afectó muy poco a la invertasa. Esta fue mucho más sensitiva a las variaciones de luz en las plantas que se trataron con concentraciones altas de $\mathrm{NO}_{3}$, pero la disminución inducida por la oscuridad no mejoró con la aplicación de altas concentraciones de $\mathrm{NO}_{3}$.

9. La amilasa foliar se inactivó en ausencia de la luz. Se propone la presencia de un mecanismo de sintesis foliar en el que la oscuridad destruye un componente esencial. La actividad de la enzima aumentó gradualmente en el tejido reservante tierno a causa de una oscuridad prolongada. Se sugirió que un inhibidor natural de la enzima se produce en presencia de la luz y se destruye en la oscuridad.

10. Las concentraciones variables de $\mathrm{NO}_{3}$ modificaron la disminución de la amilasa inducida por la oscuridad, pero no lograron impedir eficazmente la tendencia a disminuir o provocar una mayor recuperación después de la reiluminación. Las plantas tratadas con concentraciones altas de $\mathrm{NO}_{8}$ logra- 
ron una recuperación parcial de la amilasa. La inactivación causada por una baja concentración de $\mathrm{NO}_{3}$ que se observó al principio del tratamiento con luz persistía al final del estudio.

11. La inactivación de la amilasa causada por una concentración baja de $\mathrm{NO}_{3}$ también persistió en el tejido reservante tierno. Este comportamiento de la amilasa, con frecuencia observado anteriormente, parece ser un denominador común en la caña de azúcar que se somete a un impacto fisiológico. El fracaso de los tratamientos con luz en alterar el comportamiento preestablecido de la amilasa se considera como uno de los hallazgos más importantes de este estudio.

12. La inactivación de la amilasa foliar causada por el AG desaparecio 2 horas después de haber comenzado el período de permanencia en la oscuridad. Sin embargo, en el tejido reservante tierno, la inactivación causada por el AG que no se manifestó al inicio del tratamiento, se desarrolló gradualmente en las plantas que permanecieron en la oscuridad. A esta inactivación le siguió un aumento masivo de amilasa inmediatamente después de la reiluminación. Se concluye que el AG aumentó la sensitividad a la luz de la amilasa presente, interfirió con el ritmo endógeno de la amilasa y propició la síntesis. También se observó un aumento en la síntesis de los inhibidores naturales de la amilasa.

13. La ATP-asa foliar acusó una moderada pero persistente inactivación en las plantas que permanecieron en la oscuridad. La actividad no descendió a menos de un 50 por ciento de los valores registrados al comienzo, y al reiluminarse no se logró recuperación alguna. La ATP-asa en las plantas que permanecieron en la oscuridad siguió el mismo ritmo endógeno de las plantas testigo que se dejaron en el invernadero.

14. La inactivación inicial de la ATP-asa se mantuvo igual, pero sin aumentar en la oscuridad. Las plantas que se trataron con concentraciones altas de $\mathrm{NO}_{3}$ acusaron un descenso más severo de ATP-asa que las plantas testigo o las tratadas con bajas concentraciones. Sin embargo, este descenso no sobrepasó el nivel crítico establecido por una baja concentración de $\mathrm{NO}_{3}$. Se concluye, pues, que alrededor de la mitad de la energía potencial aparente de la ATP-asa es sensitiva a tratamientos con luz y $\mathrm{NO}_{3}$. Tal parece que hay una porción suficiente del potencial de la ATP-asa insensitiva a la luz, lo cual permite las funciones esenciales de la enzima. Puede ser que para la sintesis de la ATP-asa estén presentes dos mecanismos en la caña de azúcar. Se sugiere la presencia de dos tipos de ATP-asa, cada uno con diferente grado de sensitividad a la luz.

15. En los dos grupos de plantas tratadas con $\mathrm{NO}_{3}$, la ATP-asa respondió en formas opuestas a los cambios de ambos grupos de control que se observaron inmediatamente después de la reiluminación. La deficiencia de 
nitrógeno, no importa los niveles especificos de $\mathrm{NO}_{3}$, trascendió los efectos de la luz y el ritmo endógeno sobre la ATP-asa.

16. El AG causó la disminución de la ATP-asa en el tejido reservante tierno. Se requirieron 48 horas de oscuridad para registrarse totalmente el efecto del AG. De nuevo, la ATP-asa resistió una disminución inferior a un nivel de 50 por ciento.

\section{LITERATURE CITED}

1. Alexander, A. G., Sucrose-enzyme relationships in immature sugarcane as affected by variable nitrate and potassium supplied in sand culture, J. Agr. Univ. P.R. 48 (3): 165-231, 1964.

2. - Behavior of enzymes governing starch and sucrose-forming pathways in two sugarcane varieties supplied with variable nitrate and phosphate in sand culture, J. Agr. Univ. P.R. 49 (2): 153-75, 1965.

3. - Induction of varying sugar levels in leaves of immature sugarcane with acid phosphatase inhibitors, J. Agr. Univ. P.R. 49 (1): 35-59, 1965.

4. - Hydrolytic proteins of sugarcane: The acid phosphatases, J. Agr. Univ. P.R. 49 (2): 204-28, 1965.

4. - Hydrolytic proteins of sugarcane: The acid invertases, J. Agr. Univ. P.R. 49 (3): 207-30, 1965.

6. - Hydrolytic proteins of sugarcane: Amylase, J. Agr. Univ. P.R. 49 (3): 308-24, 1965.

7. - Effects of tungsten and molybdenum on sucrose content and hydrolytic enzymes of immature sugarcane, J. Agr. Univ. P.R. 49 (4): 429-42, 1965.

8. - , and Samuels, G., Controlled-temperature studies of growth, enzymology, and sucrose production of two sugarcane varieties in Puerto Rico, J. Agr. Univ. P.R. 58 (3): 204-17, 1968.

9. Alexander, A. G., Interrelationships of gibberellic acid and nitrate in sugar production and enzyme activity of sugarcane, J.Agr. Univ. P.R. $52(1): 19-28,1968$.

10. - Effects of combined silicon and gibberellic acid on enzyme behavior and sucrose content of immature sugarcane, Proc. Int. Soc. Sugarcane Technol. 18: 522-23, 1969.

11. - Growth, enzyme, and sugar responses of immature sugarcane to foliar treatment with 6-azauracil and gibberellic acid, J. Agr. Univ. P.R. 58 (4): 295-310, 1968.

12. - The potential of sugarcane to produce sucrose, Proc. XIII Cong. Int. Soc. Sugar Cane Technol. 18: 1-24, 1969.

13. - - High sucrose and abnormal enzyme activity as a function of nutritional stress in sugarcane, J. Agr. Univ. P.R. 51 (4): 325-33, 1967.

14. - Interrelationships of nitrate and 6-azauracil in the growth, enzymology, and sucrose production of immature sugarcane, J.Agr. Univ. P.R. 68 (2): 81-92, 1969.

15. - Relationships of gibberellic acid to water and phosphorus in the growth, sugar production, and enzyme behavior of sugarcane, J.Agr. Univ. P.R. 58 (3): $149-66,1969$.

16. Alexander, A. G., and Montalvo-Zapata, R., Enzyme studies of sucrose decline in sugarcane desiccated with Paraquat, J. Agr. Univ. P.R. 58 (4): 230-50, 1966

17. - Relationships of light to enzyme and sucrose transformations in sugarcane treated with Paraquat, J. Agr. Univ. P.R. 54 (2): 264-96 1970. 
18. Bennun, A., and Avron, M., Light-dependent and light-triggered adenosine triphosphatases in chloroplasts, Biochem. Biophys. Acta 79: 646-8, 1964.

19. - The relation of the light-dependent and light-triggered adenosine triphosphatases to photophosphorylation, Biochem. Biophys Acla 109: 117-27, 1965.

20. Bull, T. A., The effects of temperature, variety, and age on the responses of Saccharum spp. to applied gibberellic acid, Aust. J. Agr. Res. 15: 77-84, 1964.

21. Cardini, C. E., Leloir, L. F., and Chiriboga, J., The biosynthesis of sucrose, $J$. Biol. Chem. 214: 149-55, 1955.

22. Conference on coordination of basic research programs of sugarcane agriculture, David North Research Center, Queensland, Australia. Personal communication with Dr. A. Vlitos, 1967.

23. Dube, S. K., and Nordin, P., Isolation and properties of sorghum alpha-amylase, Arch. Biochem. and Biophys. 94: 121-7, 1961.

24. Hartt, C. E., Kortschak, H. P., Forbes, A. J., and Burr, G. O., Translocation of $C^{14}$ in sugarcane, Plant Physiol. 98 (3): 305-18, 1963.

25. Hartt, C. E., Effect of moisture supply upon translocation and storage of $C^{14}$ in sugarcane, Plant Physiol. 48 (3): 338-46, 1967.

26. Hatch, M. D., and Glasziou, K. T., Sugar accumulation cycle in sugarcane. II. Relationship of invertase activity to sugar content and growth rate in storage tissue of plants grown in controlled environments, Plant Physiol. 88: 344-8, 1963.

27. Kaufman, P. B., Ghosheh, N., and Tkuma, H., Promotion of growth and invertase activity by gibberellic acid in developing Avena internodes, Plant Physiol. 48: 29-34, 1968.

28. Paleg, L. G., Physiological effect of gibberellic acid. I. On carbohydrate metabolism and amylase activity of barley endosperm, Plant Physiol. 35: 293-9, 1960.

29. - Physiological effects of gibberellic acid. II. On starch hydrolyzing enzymes of barley endosperm, Plant Physiol. 35: 902-6, 1960.

30. Sutherland, E. W., Cori, C. F., Haynes, R., and Olsen, N. S., Purification of the hyperglycemic-glycogenolytic factor from insulin and from gastric mucosa, $J$. Biol. Chem. 180: 825-37, 1949.

31. Swain, R. R., and Dekker, E. E., Seed germination studies. II. Properties of a cell-free amino acid incorporating system from pea cotyledons; possible origin of cotyledonary alpha-amylase, Plant Physiol. 44: (3): 319-25, 1969.

32. Tanimoto, T., and Nickel, L. G., Re-evaluation of gibberellin for field use in Hawaii, Rept. Haw. Sug. Technol., 25th Annual Meeting, pp. 184-90, 1966. 